Journal of Universal Language 6

September 2005, 53-84

\title{
Noun Phrases in L2 French and Haitian: Clues on the Origin of Plantation Creoles
}

\author{
Patrick-André Mather \\ Universidad de Puerto Rico
}

\begin{abstract}
This article provides evidence from studies on second language acquisition in support of the gradualist model of creole genesis. According to this model, creole genesis is viewed as a gradual process away from the lexifier language, as successive generations of African slaves acquired increasingly divergent varieties of the emerging contact language. This article provides examples on the L2 acquisition of French, and compares interlanguage structures with Haitian, a radical French-lexifier creole. Using examples within the NP domain, I conclude that many creole features can be accounted for in terms of second language acquisition, either as 1) the transfer of L1 features (via e.g., relexification), 2) the acquisition of L2 features, or 3) interlanguage structures found neither in the L1 or the L2, including innovations (e.g., reanalysis or grammaticalization) or other developmental stages in second language acquisition. The article also discusses the origin of tense-mood-aspect markers, which are not attested in the L2 data and may be better explained in terms of first, rather than second language acquisition processes.
\end{abstract}

Keywords: acquisition, creole, French, Haitian, interlanguage 
54 Noun Phrases in L2 French and Haitian: Clues on the Origin

\section{On the "Sla/Gradualist" Model of Creole Genesis}

Over the past twenty years, several linguists have argued that creole genesis is best described as a gradual process involving successive stages in the acquisition of L2 French or L2 English (e.g., Arends 1995; Chaudenson 1981, 1989; Migge 1998; Singler 1996). This theory can be called the SLA/gradualist model of creole genesis. Though most plantation creoles arose in the $17^{\text {th }}$ and $18^{\text {th }}$ centuries, today many co-exist with their European lexifier language, and there are a series of intermediate registers or "lects" between the acrolectal creole varieties, close to the lexifier language, and basilectal varieties, whose grammar has diverged considerably from that of the lexifier. According to the gradualist model, the acrolectal varieties pre-date the mesolectal and basilectal varieties. Creole genesis is viewed as a gradual process away from the lexifier language, toward increasing basilectalization, as successive generations of African slaves acquired increasingly divergent varieties of, and introduced substratum features into, the emerging contact language. The developmental stages of creoles, represented by the various lects within the creole continuum, are analogous, though not identical, to successive interlanguage stages.

Chaudenson $(1989,1995)$ distinguishes two phases in the settlement of plantation colonies: the société d'habitation (small farming units) and the société de plantation (large-scale sugar plantations). In the société d'habitation, the white population formed a majority, the farms were small and the number of slaves limited. At this time, superstrate and substrate speakers lived in close contact. It is likely that L2 varieties of French, similar perhaps to present-day L2 varieties spoken in West Africa, developed during this phase. At this initial stage, what occurred was a simple case of shift-induced language change. The resulting varieties were not creoles, but rather varieties of French close to the acrolectal varieties 
of contemporary creoles. However, during the sugar boom, large plantations were created (sociétés de plantation) which required large numbers of slaves. Depending on the island colony, the sugar boom generally occurred during the first decades of the $18^{\text {th }}$ century. In this new society, the slaves of the first generation, who had acquired an L2 variety of French during the first phase of settlement, are assumed to have become the intermediaries between the white masters and the new slaves who had no direct contact with L1 speakers of French. This particular situation is what distinguishes creole genesis from 'regular' second-language acquisition: the L2 variety of the first slaves became the target language of the incoming slaves, whose pidginized variety in turn became the target of the more recent arrivals (Chaudenson 1989: 74). Thus, creole genesis is a very specific process which requires the particular social and historical conditions that existed in the early $18^{\text {th }}$ century in plantation colonies founded by Europeans.

Creole genesis requires a combination of factors, including (i) the absence of normative pressure in a highly variable linguistic environment (different dialects spoken by the European settlers, different varieties of L2 French); and (ii) the 'importation' of large numbers of slaves of various linguistic backgrounds, who are social inferiors and are cut off from their L1 language communities and have restricted access to the Europeans. As formulated, this model of creole genesis applies only to exogenous European plantation creoles, i.e., where both the slaves and Europeans were immigrants. However, this model is by no means restricted to French plantation colonies: for example, Migge (1998) shows that the settlement of Suriname followed the sequence described by Chaudenson (1989, 1995): From 1652 to 1670, during the English presence, Suriname had mainly small farming units which "were not characterized by strict social segregation between Europeans and Africans on the one hand, or between masters and servants on the other." After 1684, the situation gradually changed, and the large-scale sugar plantations 
56 Noun Phrases in L2 French and Haitian: Clues on the Origin

which emerged were "strictly hierarchical, characterized by a relatively strict social segregation between Europeans and Africans" (Migge 1998: 226-227).

Thus creole genesis can be described as a kind of second language acquisition 'in reverse', in the sense that while the early stages of creole genesis were quasi normal second language acquisition, the end-stage produced a language (basilectal creole) markedly different from the European lexifier. By contrast, in 'successful' L2A the end-stage of acquisition is closer to the target language than the initial stages. Thus, the phylogenesis of creoles (as E(xternalized)-languages in the sense of Chomsky (1986), i.e., a language shared by a community of speakers) is a mirror image of the ontogenesis of an L2 grammar as constructed/represented in the mind of the individual speaker (or I(nternalized)-language). In particular, there is more L1 transfer in early stages of L2 acquisition, as there are more substratum features in the basilectal varieties of plantation creoles, which are more recent than acrolectal varieties.

If one recognizes that creole genesis is a particular instance of language change due to external causes (since two or more languages are interacting), it follows that creolization cannot be fully understood without reference to theories of second language acquisition. Similarly, regular language change which is not due to language contact could conceivably be subsumed under a general theory of first language acquisition. But this is a topic for another article.

Three kinds of evidence can help support my claim that creole genesis is best described as a succession of (increasingly 'deviant') fossilized interlanguages, acquired over several generations. First, current research in second language acquisition may yield valuable insights into the cognitive mechanisms of creolization, including L1 transfer, selective acquisition of L2 structures, reanalysis and fossilization of interlanguage structures. In the following, evidence of this kind will be adduced to illustrate parallels between creolistics 
and SLA theory. Second, case studies of West African L2 French can give us an idea of the initial stages of creolization, which Chaudenson (1995) and Singler (1996) defined as quasi normal L2A. Third, the creole continua that exist to this day on several former plantation colonies, including Réunion and Martinique, may very well represent a survival of the successive stages of creole genesis in the $17^{\text {th }}$ and $18^{\text {th }}$ centuries, with the acrolectal varieties being the oldest, and the mesolectal and basilectal varieties representing successive developments.

In the following, I will produce evidence that many structures found in French-lexifier creoles have significant parallels in L2 varieties of French, in particular with respect to issues of word order within the noun phrase.

\section{L1 or L2 Acquisition?}

One major point of debate is the respective role of adults versus children in creole genesis. Although I (along with others, e.g., Jourdan 1991, Jourdan \& Keesing 1997, Mufwene 1999, Lumsden 1999) believe there is strong evidence that nativization is not a prerequisite for creolization, it may still have a 'regulating' effect on the emerging creole (DeGraff 1999a: 488).

Most traditional accounts of creole genesis propose a two-stage process, in which a (rudimentary) pidgin is nativized and expanded by children acquiring the pidgin of their parents. This view has been echoed in recent literature: For example, DeGraff (1999b: 16) suggests that Afactors involved in creolization... include the influence of the early (pre-creole) pidgin with its high instability and limited linguistic repertoire and the influence of massive contact between typologically distinct languages." It has even been suggested that these putative pidgins were perhaps inconsistent with UG principles, and that they are "somewhat 'lesser' languages, to 
58 Noun Phrases in L2 French and Haitian: Clues on the Origin

the extent that they are less complex than full-fledged languages like creoles" (DeGraff 1999a: 499). Yet, what is known of the sociohistorical contexts in which Caribbean and Indian Ocean creoles emerged (see previous section) suggests that, in these colonies, the initial stages of creole genesis in fact approximated quasi-normal second language acquisition, as suggested by Chaudenson (1989, 1995) and Singler (1996). This gradualist view is incompatible with the suggestion that the creators of creoles first spoke some macaronic, 'pre-UG' pidgin. Perhaps individual learners, in building their own I-language, went through an initial, 'pidgin' stage, as most L2 learners do, but there is no evidence that there ever was a pidgin E-language (in the sense of DeGraff 1999b) which preceded the emergence of a creole E-language.

Another problem some 'pidgin-into-creole' accounts (e.g., Bickerton's Bioprogram model), is that they seem to assume that the children who allegedly created the creole were never influenced by their parents' L1. However, Sebba (1997: 179) points out that "bilingualism rather than monolingualism in the creole is likely to be the norm in such a community". An important point made by Baker (1995: 17), which has been made for other creoles (albeit in different socio-historical circumstances, e.g., Tok Pisin, Pijin-see Jourdan 1991, Jourdan \& Keesing 1997), is that "nativization appears to have had a negligible effect on speed of development. The simplest explanation might be that, contrary to the suppositions of Bickerton (1981), most children born on slave plantations did acquire one or more language(s) in addition to the emerging contact language." The corollary of this is that in most plantation colonies, the contact language emerged slowly and gradually gained ground over (West)African languages, a point also made by Fleischmann (1984) and Bartens (1996: 135), who argue that the slaves in the new world probably remained bilingual for a relatively long time in their native languages and in the incipient creole. This type of prolonged contact set the stage for continued substratum interference in 
the phonology and syntax.

According to Fleischmann (1986: 68-69), in the French Caribbean, until 1800 at least $50 \%$ of slaves were Abozales, i.e., slaves who were not born in the plantation colonies. Thus, there was a majority of "pidgin" speakers until 1800 . Yet, by 1700 there were already creoles in several Caribbean islands, including Haiti, Martinique \& Guadeloupe. For example, McWhorter (1998: 800) quotes a Martinique Creole text dated 1671, i.e., less than 40 years after the initial settlement of the island by the French in 1635. This suggests that for 100 years at least most slaves spoke the creole as an L2, i.e., as a stabilized, expanded pidgin. With little or no corrective feedback, it is likely that shift-induced intereference from the Abozales was important, especially if the shifting-speakers outnumbered the native creole speakers for 100 years.

Concerning the cognitive mechanisms at work in language change, DeGraff (1999a, b) and Lightfoot (1999a, b), among others, have argued that the I-grammar of a language is recreated in the minds of each new generation of speakers, and that children acquiring a language create a grammar based on the input. As such, language is not transmitted from one generation to the next: it is recreated by each new generation of speakers, based on cues provided in the input. Therefore, the question as to whether creoles are or are not genetically related to their lexifiers is a terminological debate, a definitional problem, not a theoretical one. Lightfoot (1999b) shows that, in "ordinary" language change, successive generations of speakers sometimes reanalyse certain words as belonging to different lexical categories. A case in point is the reanalysis of certain Middle English verbs as a new lexical class, namely modals, when verbs no longer moved up to Infl in the Igrammar of new generations of speakers. In cognitive terms, creole genesis can only be the result of first and/or second language acquisition processes. The creators of creoles constructed grammars on the basis of various cues and inputs, in much the same way as 
60 Noun Phrases in L2 French and Haitian: Clues on the Origin

first or second language learners construct their own mental representations of their L1 or L2.

In the gradualist/SLA model of creole genesis, the principle of 'recreation' may be thought to apply to the L2 acquisition of a rapidly evolving language over several generations, i.e., speakers construct an abstract grammar on the basis of (restricted?) input from the previous generation of L2 speakers. The difference is that we are dealing not with L1 speakers, but with successive generations of L2 speakers, and therefore with the cumulative effect of several layers of "learner's mistakes", including L1 transfer. This idea is expressed by Chaudenson (1995: 93).

In this scenario, the initial stages of creolization would look something like L2 varieties of French. In view of the fact that the creators of these L2 varieties were native speakers of Niger-Congo languages, L2 French varieties as spoken by West Africans today could provide a useful point of departure for further discussion. In the following sections I will examine such interlanguage varieties.

\section{The Structure of Noun Phrases in Haitian and L2 French}

In the following I will compare various structures found in French-lexifier creoles, in particular Haitian, and compare them with similar structures reported in studies on French second language acquisition. The core of my argument is that if a given L1 feature is found to be transferred in the L2 French of, say, a speaker of Ewe in present-day Togo (West Africa), then there is reason to believe that in the $17^{\text {th }}$ and $18^{\text {th }}$ centuries, speakers of Ewe acquiring L2 French as slaves in the Caribbean also transferred this feature into the incipient creole. While the social circumstances are very different, the cognitive/mental processes involved in second language acquisition have not changed in 300 years, so the two situations are 
presumably comparable in terms of their linguistic outcomes. In particular, I will show that many of the putative substratum features found in present-day creoles are attested in current studies on second language acquisition. This does not mean that all features found in creoles are the result of L1 transfer: second-language acquisition also allows for the successful acquisition of L2 structures (trivially), the reanalysis of some L2 structures, or the introduction of parameter settings different from both L1 (substrate) and L2 (superstrate). In this paper it is argued that many creole structures can be accounted for in terms of SLA processes, whether they mirror substrate structures, superstrate structures, or structures distinct from both L1 and L2, since all of these possibilities are well documented in SLA studies. In short: if creoles are indeed the result of second language acquisition over several generations, then this must be supported by current data on second language acquisition, since any theory must be both testable and falsifiable to have any explanatory value.

It should be pointed out here that although interlanguage stages are considered analogous to intermediate 'lects' in creole continua, they are not identical. For one thing, each 'lect' in the creole continuum represents the fossilized end-stage of acquisition, and represents a fully-fledged language with all the lexical and stylistic resources of a 'normal' language. By contrast, the various examples taken from studies on European interlanguages represent interlanguages that are often quite deficient in terms of vocabulary, stylistic resources, etc. The utterances of Ewe learners of French can provide an indication of the L2 French input that was subsequently restructured by the second, third, etc. generations of learners.

Examples of West African languages are based on three dialects of Ewe (Gbe), a language that belongs to the Kwa family: Ewe (Lafage 1985), Fongbe (Lefebvre 1998) and Gengbe (Kangni 1989). Examples of Haitian are taken mainly from Lefebvre (1998a, 1998b) and Valdman (1978). The L2 French examples from Lafage (1985) 
62 Noun Phrases in L2 French and Haitian: Clues on the Origin

are particularly relevant here, since speakers of Ewe and closely related Kwa languages were among the creators of Haitian and other French-lexifier creoles in the Caribbean, as documented e.g., in Singler (1996) and Lefebvre (1998b).

\subsection{The Position of Determiners within the NP}

The position of the specifier, adjectives and complements within the noun phrase is a salient syntactic feature, and is readily identifiable in both creoles and in L2 varieties of European languages. As noted by Lefebvre (1998a: 94), the definite article is post-nominal in both Haitian and Fongbe:

(1) M manje krab la. (Haitian Creole)

I eat crab Det

'I ate the crab (in question/that we know of).'

(2) $\mathrm{N} d u$ ason o. (Fongbe)

I eat crab Det

'I ate the crab (in question/that we know of).'

As shown in the following examples, determiners are invariably post-nominal in dialects of Ewe:

(3) nyonù-à

woman-the(SING)

(4) nyonù-wó (Ewe; Lafage 1985: 242)

woman-the(PLUR)

(5) molu a bi vò.

rice Det cooked already

'The rice is already cooked.' (Gengbe; Kangni 1989: 15) 
(6) èkplo a lè xo à mè. table Det be-at room Det inside 'The table (in question) is in the room.'

(Gengbe; Kangni 1989: 15)

(7) àwù yà ze.

suit Dem torn

'This suit is torn.'

(Gengbe; Kangni 1989: 15)

(8) èkplo nwa sì.

table Dem old

'This table is old.'

(Gengbe; Kangni 1989: 15)

Interestingly, there are examples of post-posed determiners in the L2 French of L1 Ewe speakers, as illustrated in the examples below:

(9) N'y a qu'à pousser auto-là.

'All you need to do is to push the car.'

(L2 French, L1 Ewe; Lafage 1985: 409)

(10) Femme là, c'est méchant.

woman the, it is evil

'The woman is evil.'

Standard French: La femme est méchante.

(Lafage 1985: 407)

(11) Patron là il a dit...

boss the he has said

'The boss said...'

Standard French: Le patron, il a dit.

(Lafage 1985: 412) 
64 Noun Phrases in L2 French and Haitian: Clues on the Origin

(12) La police va arrêter voleurs là. the police will arrest thieves the/there 'The police will arrest these thieves.' Standard French: La police va arrêter les voleurs.

(Lafage 1985: 416)

While it is true that the French demonstrative -là can be suffixed to a noun (especially in overseas varieties like Québec French), it must be used in addition to the pre-posed definite article (in Québec French) or demonstrative (in Standard French), and it has a demonstrative meaning which is more marked than in Haitian, Fongbe, and the L2 French example above. This suggests that the position of the specifier in the L1 can be transferred into the L2 interlanguage, as evidenced by the Haitian and L2 French data.

It should be noted that, in Ewe, the plural marker wo is homophonous with the $3^{\text {rd }}$ person plural pronoun. The same is true for the plural marker yo in Haitian, suggesting transfer from the West African substrate:

(13) Wo bla $\varepsilon$. they bind him/her

'They bound him/her.'

(Gengbe; Kangni 1989: 50)

(14) Sùkulùvi wo yì sùkulù. pupil PL go school

'The pupils went to school.' (Gengbe; Kangni 1989: 50)

(15) Apre yo fin wè-1 yo rakònte... after they finish see-him they tell... 'After they had seen him, they told...' 
(16) krab yo
crab PL
'the crabs' (Haitian; Lefebvre 1998b: 85)

In addition to articles, Lafage (1985) found other examples of post-posed determiners in the L2 French of L1 Ewe speakers, including the oblique form of the personal pronoun used to express possession:

(17) Père-lui c'est mort.

father-him it's dead.

'His father is dead.'

Standard French: Son père est mort.

(L2 French, L1 Ewe; Lafage 1985: 417)

(18) père-moi

father-me

'my father'

Standard French: mon père

As shown in examples (17) and (18), instead of using the French preposed possessive pronoun (mon, ton, son...), L1 Ewe speakers postpose the oblique (strong) form of the personal pronoun to express possession. This mirrors usage in Ewe (Gbe), where first and second person singular pronouns are postposed when referring to kinship terms:

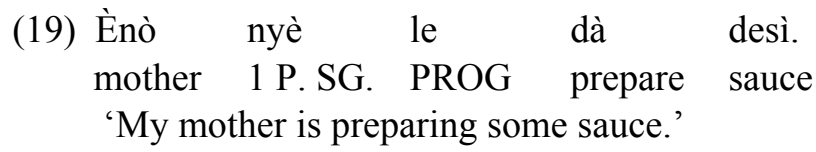

(Gengbe; Kangni 1989: 19) 
66 Noun Phrases in L2 French and Haitian: Clues on the Origin

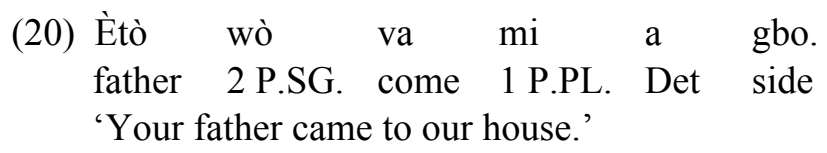

(Gengbe; Kangni 1989: 19)

What is striking here is that pattern is found in several Frenchlexifier creoles, including Haitian. According to Lefebvre (1986: 131), "in [Haitian] nominal structures, personal pronouns [derived from the oblique form of the French personal pronoun] are used to indicate possession":

(21) liv mwen /u /li /... /yo (Haitian; ibid: 131) book I /you /he $/ .$. . / they 'my / your / his / ... / their book'

(22) liv li yo (Haitian; ibid: 131) book he PL 'his books'

However, as noted above, personal pronouns, when used as possessive advectives, are postposed in Ewe only for kinship terms, as reflected in the L2 French examples. For other nouns, the personal pronoun is preposed and is used along with a post-posed determiner, as illustrated by the following example:

(23) Àpê àwù à zè.

POSS suit Det torn

'My suit is torn.'

(Gengbe; Kangni 1989: 18)

In Haitian, on the other hand, post-posed pronouns are used as possessives with all nouns. Perhaps Ewe speakers, who were among the creators of Haitian, generalized the post-nominal possessive to all nouns, following the pattern in L2 French. Another possibility is 
that the Haitian pattern is derived from a common pattern in colloquial French. Indeed, certain Haitian dialects (DeGraff, p.c.; see also Valdman 1978: 189) produce variants like Liv a mwen and Liv a li, which can be compared to colloquial/regional French mon livre à moi, son livre à lui where the post-nominal oblique pronouns "double" the prenominal possessive. This post-nominal oblique can be interpreted as making the possessor more salient and transparent. With this in mind, a comparison of Haitian liv (a) mwen and French mon livre à moi might suggest one more instance of reanalysis whereby saliency and transparency played a key role in language learners' restructuring of target. From this perspective, the Haitian examples in (21) and (22) may contain a null counterpart of $\grave{a}$, perhaps the result of further phonetic erosion-another common factor in reanalysis/grammaticalization scenarios. This alternate scenario does not a priori exclude substrate transfer, but shows that two complementary SLA processes may be at work here.

In addition, although the Haitian definite article, plural marker, and possessive marker seem to follow the L1 pattern (Gbe), by contrast, the indefinite article yon, cardinal determiners (de 'two', twa 'three', etc), ordinal determiners (premyer ' $1{ }^{\text {st }}$, dezyèm ' 2 nd, twazyèm ' 3 rd, etc.), wh-determiners (e.g., $k i$ 'which'), and quantifiers (e.g., chak 'each', tout 'every', okenn 'no', nenpòt 'any') are all prenominal, like in French, and thus follow the L2 pattern, as illustrated in the following examples from Valdman (1978: 186-187; English translations mine):

(23) dé zwazo 'two birds'

(24) lòt jou 'the other day'

(25) kèk wòch 'a few pebbles'

(26) chak bèt 'each animal'
St. Fr: deux oiseaux

St. Fr: 1'autre jour

St. Fr: quelques cailloux

St. Fr: chaque animal 
68 Noun Phrases in L2 French and Haitian: Clues on the Origin

(27) anpil diri 'lots of rice' St. Fr: beaucoup de riz

(28) okenn pitit 'no children' St. Fr: aucun enfant; pas d'enfants

(29) plizié choual 'several horses' St. Fr: plusieurs chevaux

Thus, in Haitian, these determiners follow the word-order of the superstrate (French), which in SLA terms suggests successful acquisition of the L2 word-order by the creators of Haitian, since many noun determiners in Haitian are distributionally similar to their French cognates and dissimilar to their Gbe counterparts. By contrast, the post-position of all functional heads within the nominal phrase seems a widespread fact across Gbe languages. For example, in Fongbe (Anynomous 1983: 25), determiners and adjectives follow the noun in the following order: possession, gender, adjectives, numerals, demonstratives, definite determiners.

\subsection{The Position of Adjectives within the NP}

Another potential area of parametric variation within noun phrases is the position of adjectives. Again, there is evidence that in some L2 varieties of European languages, adjectives and complements are misplaced with respect to target language parameter settings. Furthermore, the placement of adjectives in both L2 varieties and creolized varieties of European languages often reflects L1 parameter settings, which suggests L1 transfer. For example, in L2 French spoken in southern Togo, adjectives frequently follow the noun when in standard French they should precede it. This may be due to the fact that in Ewe, adjectives invariably follow the noun (Lafage 1985: 241), but it could also be an overgeneralization since most adjectives follow the noun in French, e.g., le livre rouge ('the red book'). 
(30) àtì lóló

tree big

'a big tree'

(Ewe; Lafage 1985: 241)

(31) àgblè-à kèkè

field-the large

'the large field'

(Ewe; Lafage 1985: 246)

$\begin{array}{lllll}\text { (32) Il a } & \text { gagné } & \text { poissons } & \text { gros. } \\ \text { he } & \text { has } & \text { gotten } & \text { fish } & \text { big }\end{array}$

'He got big fish.'

Standard French: Il a attrapé de gros poissons.

(L2 French, L1 Ewe; Lafage 185: 409)

(33) Il a grimpé au cocotier grand.

he has climbed the coconut-tree big

'He climbed up the big coconut tree.'

Standard French: Il a grimpé au grand cocotier.

(Lafage 1985: 271)

However, The counterparts of (32) and (33) in Haitian Creole are as in (34) and (35):

(34) gwo pwason... [Haitian Creole]

big fish

(35) gran pye-kokoye... [Haitian Creole] big coconut-tree

Thus, Haitian creole has mixed $\mathrm{N}+\mathrm{A}$ and $\mathrm{A}+\mathrm{N}$, just like French, even though Ewe (and other closely related substrata) has a fixed noun+adjective order. According to Savain (1993: 51), 'definite' adjectives 
70 Noun Phrases in L2 French and Haitian: Clues on the Origin

(colors for example) come after the noun in Haitian:

$$
\begin{array}{lll}
\text { (36) yon soulye } & \text { blan } \\
\text { a } & \text { shoe } & \text { white } \\
\text { 'a white shoe' } &
\end{array}
$$

Before the noun, we find only indefinite articles, other 'indefinite' determiners like kèk ('some'), plizye ('a few'), and a limited number of definite adjectives, including bèl ('nice'), bon ('good'), gwo ('big'), gran ('tall'), as pointed out in Valdman (1978: 187). Many other Haitian adjectives are post-nominal, and the same holds for many French adjectives. In addition, certain adjectives in Haitian Creole and in French can be both pre- and post-nominal, often with interesting and quite subtle semantic differences.

Thus, in the case of Haitian, we seem to have a case of "successful" acquisition of the French word-order for adjectives, rather than the L1 transfer predicted by the L2 French data. Note that the relexification hypothesis also predicts this fact, since "the word order of major category lexical entries is predicted to follow the word order of lexical categories in the superstratum language" (Lefebvre 1998: 39).

\subsection{Use (and Omission) of Noun Determiners}

In many French-lexifier creoles, preposed French determiners

\begin{tabular}{|c|c|c|}
\hline (37) a. zanfan & 'child' & (French; les enfants) \\
\hline b. dilo & 'water' & (French; de l'eau) \\
\hline c. lera & 'rat' & (French; le rat) \\
\hline d. lamer & 'sea' & (French; la mer) \\
\hline
\end{tabular}
have been reanalyzed as part of the root noun, as in the following examples from Mauritian (Baker \& Corne 1986: 170): 
There are apparently over 550 such examples in Mauritian. Baker \& Corne (1986: 170-172) claim that this "agglutination" of the French article is due to Bantu substrate influence. Indeed, Bantu nouns have unstressed class prefixes, so when Bantu speakers tried to learn L2 French they may have reanalyzed French articles as unstressed prefixes.

Though this reanalysis is not surprising (it is also found in child L1 varieties of French), it is significant that West African L2 speakers of French also tend to amalgamate the article and the noun, even though Kwa languages do not have class prefixes. Therefore, this reanalysis can occur regardless of whether there are class prefixes in the L1. Consider the following examples from L2 French by L1 Ewe speakers:

(38) Y'a un l'école. there's a the-school

'There is a school.'

(Lafage 1985: 410)

(39) C'est beaucoup l'auto pour Lomé. (ibid) it's many the-car for Lomé

'There are many cars in Lome.'

(40) des nenfants, le oiseau

DET children, DET bird (Lafage 1985: 409)

Similar examples are found in Caribbean creoles: according to Baker \& Corne (1986: 170), there are between 100 and 200 words with 'agglutinated' articles in each of the French-lexifier Caribbean creoles, compared with 550 for Indian Ocean creoles, which suggests that L1 transfer from Bantu languages reinforced the tendency to 'agglutinate' articles. If West African L2 speakers of French reanalyze articles as part of the noun, it is not surprising that the creators of French-lexifier creoles also used this reanalysis. Here, 
72 Noun Phrases in L2 French and Haitian: Clues on the Origin

the argument for L1 influence is that articles in most West African languages are postposed, not preposed as in French, leading to a reanalysis of French articles as part of the noun. In other words, the L1 grammar could not parse 'Det+Noun' strings, so it simply assumed that they were bare nouns.

Given that articles are always postposed in Ewe and Fongbe, and that indefiniteness in both languages is usually expressed by a bare noun, Ewe learners of French tend to omit articles, as in the following examples (Lafage 1985: 256):

(41) C'est pas poulet

it is not chicken

'It's not a chicken.'

Standard French: C'est pas un poulet.

(42)

Il a tué pintade

he has killed bird

'He has killed a bird'

Standard French: Il a tué une pintade.

(43) Donner cadeau

give present

'to give a present'

Standard French: Donner un cadeau.

In Standard French, examples (41) to (43) above take a preposed indefinite article. This interference feature of West African L2 French is also found in Haitian, which, according to Lefebvre (1986: 293), has no indefinite article, as noted above. Relevant examples are repeated here for ease of reference:

$$
\begin{array}{llr}
\text { (44) da } \text { o } & \text { (Fongbe) } \\
\text { sèpa a } & \text { (Haitian) } \\
\text { the snake }[+ \text { definite] }
\end{array}
$$


(45) da (Fongbe)

sèpa (Haitian)

snake (generic or [-definite])

The same pattern exists in Gengbe, another dialect of Ewe:

(45) Molu a

(Gengbe; Kangni 1989: 15)

rice Det

'the rice' [+definite]

(46) èsì fafaa

(Gengbe; Kangni 1989: 16)

water fresh

'fresh water' [-definite]

To have a general idea of how creolization can be the end-result of a succession of interlanguage varieties of European lexifier languages, one can mention the use of the French adverb là ('there'), which is also used in NPs as an enclitic to intensify the demonstrative article: cet homme-là ('this man'). Manessy (1984: 45) notes that, in West African French, là is used much more frequently than in Standard French, and can follow nouns, verbs or sentences, and is often used as the normal form of the definite or demonstrative article: "En français d'Afrique la distribution de cette marque d'insistance [-là] est très large: on la trouve en fait après n'importe lequel des constituants de l'énonciation." [In African French, this mark of emphasis (-la) has a very wide distribution: it can be found after any constituent in the sentence]. The word là is used as a determiner in noun phrases such as ballon là (the/this ball), and this shift and expansion in the use of là in West African L2 French is probably the first step in an evolution which led to the French Caribbean creoles where là has been reanalyzed a postnominal definite article.

In the SLA literature, there is evidence from other languages that 
74 Noun Phrases in L2 French and Haitian: Clues on the Origin

speakers of languages with preposed articles make more use of articles in the target language than do speakers of languages with limited or no preposed articles, as shown in the following table from Gilbert (1983: 173).

Table 1. Frequency of Occurrence of the Definite Article in the L2 German Speakers of Different First Languages

\begin{tabular}{|l|c|}
\hline \multicolumn{1}{|c|}{ Nationality } & Percent of Occurrence of Definite Article \\
\hline Turkish & 15 \\
\hline Yugoslav & 19 \\
\hline Portuguese & 35 \\
\hline Italian & 69 \\
\hline Greek & 75 \\
\hline Spanish & 87 \\
\hline
\end{tabular}

In a study of 11 North African immigrant workers in France and of 62 Tunisian high-school pupils, Véronique (1984: 193) tried to characterize the "main difficulties encountered by Arabic speakers, monolingual or bilingual (in Berber) in the learning and use of French." He noted the omission of determiners in both spoken and written data, as in the following examples, each followed by a translation in Standard French (Véronique 1984:198):

(47) a. Garage a fermé.

'The garage closed.'

Standard French: Le garage a fermé.

b. Je demande paquet cigarettes.

'I ask for a pack of cigarettes'

Standard French: Je demande un paquet de cigarettes.

As in the examples from Lafage (1985), L1 transfer is a plausible explanation: Véronique points out that "in dialectal Arabic the 
definite article ' $\mathrm{el}$ ' can be omitted when the head noun is followed by another noun which acts as a determiner, e.g., 'weld Mohammed' (the son of Mohammed)." (1984: 198) He also points out (p. 199) that out of 22 errors in the oral data on noun phrases, 20 are omission of determiners. This type of error is infrequent in the written data, which is hardly surprising since written data is less spontaneous.

\subsection{Grammatical Gender}

In Haitian, nouns are not marked for gender. To indicate biological gender in animate nouns, mal and femèl are used: mal chat (male cat), femèl chat (female cat), as opposed to chat and chatte in French. Similarly, though articles are marked for number, nouns are not: tab la, tab yo ('the table', 'the tables'). In Ewe, only animates can be feminine or masculine. Also, personal pronouns are marked for gender neither in Ewe nor in Haitian:

(48) avu-tsu yi avu-no yi (Ewe; Lafage 1985: 250) dog-male gone dog-female gone

(49) é yì 'he/she left'

(Ewe; Lafage 1985: 250)

3 p.sg. leave

$\begin{array}{llll}\text { (50) é } & \text { gba } & \varepsilon & \text { 'he/she broke it' } \\ 3 & \text { p.sg. } & \text { break } & \text { 3p.sg.non-subj. }\end{array}$

(Gengbe; Kangni 1989: 58)

(51) Li dwe 'he/she must'

(Haitian; Lefebvre 1996: 244)

Predictably, West African L2 speakers of French tend to neutralize the masculine/feminine distinction in pronouns: 
76 Noun Phrases in L2 French and Haitian: Clues on the Origin

(52) Alors ma mère, il m' a vu et il me demande so my mother he me has seen and he me ask

'So my mother saw me and asked me...'

(Lafage 1985: 251)

\section{The Origin of Tma Markers: A Role for first Language Acquisition?}

Preverbal tense-mood-aspect markers are among the most common features of plantation creoles, and although they exist in many of the substrate languages (in particular Kwa languages), they are also attested in creoles (e.g., Mauritian) where such substrate influence is unlikely. In addition, they are not robustly attested in any SLA studies, and they therefore remain problematic for the SLA/gradualist account of creole genesis. Myhill (1991: 13) claims that Aa number of patterns of tense/aspect marking can be found in data from both creoles and second language acquisition", but admits that there is still little data on tense/aspect marking in SLA.

Concerning aspect markers, Myhill (1991) claims that, in the acquisition of English as an L2, progressive marking is first done by using the form AUX+VERB, and later on in acquisition this is replaced by VERB+"-ING" (the English present participle). This is also true of English-based creoles where basilectal varieties use a pre-verbal auxiliary and acrolectal use the present participle. This suggests that Athe -ing inflection must have been stripped off of the verb during the pidginization process, i.e., by adult $2^{\text {nd }}$ language speakers (Myhill 1991: 115).

With respect to tense, Myhill (1991: 117) shows that some second language speakers use bare verbs in foregrounded (completed action) clauses (after Kumpf 1984: 141), which is reminiscent of Bickerton's observation that, in creoles, past completives are unmarked, whereas past statives are marked for tense (anterior category). 
The evidence for TMA markers in L2 English is very thin, and (to my knowledge) non-existent in L2 French studies. Why is this? One possibility is that current (West African) L2 French is analogous to the early stages of creole genesis, when slaves (still) had access to the European lexifier language. Perhaps it is only in later stages (when access to the lexifier was more restricted) that periphrastic constructions, stripped of their inflectional endings, were reinterpreted (by children and/or adults) as bare preverbal markers. If this hypothesis is true, then TMA markers emerged only after the shift to large-scale sugar plantations, and therefore cannot be found in current varieties of L2 French, which represent an earlier stage of creolization. Is there any evidence concerning the chronology in the development of the various creole features?

According to Baker (1995: 6-7), in the French-lexifier creole Antillais, the preverbal past, future and progressive markers are first attested 36 years, 115 years and 115 years respectively after the islands were settled. For Sranan, we have 68 years, 68 years and 115 years respectively for the same TMA markers. And in Mauritian, the preverbal completive, past, future and progressive markers are first attested 13 years, 58 years, 56 years and 101 years respectively after the initial settlement of the island colony.

In sum, according to Baker (1995), features not attested in L2 French, namely TMA markers, typically appear at least 50 years after the initial settlement, i.e., after the shift from small-scale farming to large-scale sugar plantations. It is precisely from this point on that, according to Chaudenson (1989), slaves no longer had direct access to the lexifier language, and the more basilectal features of creoles emerged. Thus, Baker's (1995) evidence offers a plausible explanation for the absence of TMA markers in the initial stages of creole genesis and, hence, in West African L2 French, since both represent a stage where learners have access to the European lexifier language.

Another possibility (compatible with the first explanation) is that 
78 Noun Phrases in L2 French and Haitian: Clues on the Origin

it is first language learners (i.e., children) who created the TMA markers found in most plantation creoles, as they reanalyzed the inflectionless auxiliaries and modals of the previous generation of speakers as bare verbal markers, i.e., as a base-generated functional category. After all, even though it is probably adults who introduced most grammatical features into the incipient creoles, children too may have played a role, and TMA markers may be a case in point. This is consistent with DeGraff's (1999a: 495) proposal of a 'cascade' effect : "With respect to creole genesis, adults (beyond age 15 , say) might be the primary agents of potential innovations in L2A, whereas children play the role of stabilizers or regulators." More specifically, "children's role in [creole genesis] is to restructure/ stabilize a subset of the innovations introduced (via relexification, say) into the emerging creole grammars. That is, the aggregate PLD produced by the interlanguages of pidgin speakers would manifest, among other things, a number of relexified substrate properties (along with superstrate properties), and some of these would be used by children as triggers (or cues) for setting the corresponding creole parameters (DeGraff 1999a: 506)." It has been suggested elsewhere (Mather 2000) that the tense-mood-aspect markers found in most creoles may have been introduced by children who reanalyzed the inflectionless modals and auxiliaries of their parents as bare verbal markers. If this is the case, then first language acquisition may have played a role in creole genesis after all, along the lines of the 'cascade' effect posited by DeGraff (1999 a, b).

\section{Summary of Findings}

Before drawing a general conclusion concerning the respective role of L2A and L1A in creole genesis, it may be useful to recapitulate findings for each specific structure, based on evidence from French, L2 French, Gbe and Haitian. 
The position of determiners within the noun phrase combines some patterns which can be accounted for on the basis of L1 transfer (postnominal definite article, possessives) and some that appear to represent 'successful' acquisition of L2 patterns (the prenominal position of other determiners, e.g., quantifiers, numerals, etc.). The position of adjectives in Haitian creole follow the L2 pattern (French), rather than that of the L1. In terms of the use (and omission) of determiners, on the other hand, there is a possible combination of L1 transfer and universal stages in L1/L2 acquisition, i.e., a 'conspiracy' of at least two factors. The absence of grammatical gender in pronouns, on the other hand, clearly reflects L1 patterns.

What can one conclude from this inventory of various structures, concerning the respective role of L1 transfer and SLA universals in creole genesis?

The preceding discussion has shown that there seems to be a complex interplay between L1 transfer, universals of L2A, and acquisition of supertrate language structures. There are several instances where L1 transfer and universal SLA strategies may complement or reinforce one another. This increases the likelihood of fossilization of interlanguage structures into the incipient creole, a hypothesis that is consistent with findings in SLA theory (e.g., Selinker \& Lakshmanan's 1992 'Multiple effects principle'), and also with current accounts of creole genesis (e.g., Mufwene's 'Complementary hypothesis' [1986, 2001]).

Even though this article discusses only a small subset of structural properties of French-lexifier creoles, it is clear that one does not find an isomorphic relation between interlanguage and creole structures, nor should one expect to: As pointed out in the introduction, West African L2 French represents only the initial stage in creolization, and such interlanguage structures are hypothesized to have been provided the input for further restructuring by successive generations of L2 learners. Thus, one should not expect to find all creole structures in first generation West African 
80 Noun Phrases in L2 French and Haitian: Clues on the Origin

L2 French. The absence of TMA markers is a case in point, and we have suggested that these structures appeared later on in the creolization process, and may be due to the reanalysis of L2 French periphrastic constructions by L1 learners, along the lines suggested by DeGraff (1999a) in his 'L2A / L1A' cascade effect.

\section{References}

Andersen, R. 1981. Two Perspectives on Pidginization as Second Language Acquisition. In R. Andersen (ed.), New Dimensions in Second Language Acquisition Research 165-196. Rowley, MA: Newbury House.

Anonymous. 1983. Éléments de Recherche sur la Langue Fon. Cotonou.

Arends, J. 1995. Demographic Factors in the Formation of Sranan. In J. Arends (ed.), The Early Stages of Creolization 233-277. Amsterdam: Benjamins.

Baker, P. \& C. Corne. 1986. Universals, Substrata, and the Indian Ocean Creoles. In P. Muysken \& N. Smith (eds.), Substrata versus Universals in Creole Genesis 163-183. Amsterdam: Benjamins.

Baker, P. 1995. Some Developmental Inferences from Historical Studies of

Pidgins and Creoles. In J. Arends (ed.), The Early Stages of Creolization 1-24. Amsterdam: Benjamins.

Bartens, A. 1996. Der Kreolische Raum: Geschichte und Gegenwart. Helsinki: Suomalainen Tiedeakatemia.

Bernabé, J. 1983. Grammaire Créole. Fondas Kréyol-la. Paris: L'Harmattan. Bickerton, D. 1975. Dynamics of a Creole System. London: Cambridge University Press. 1981. Roots of Language. Ann Arbor, MI: Karoma.

Cook, V. 1993. Linguistics and Second Language Acquisition. New York: St. Martin's Press.

Chaudenson, R. 1981. Textes Créoles Anciens (La Réunion et Ile Maurice). Hamburg: Helmut Buske Verlag. L'Harmattan.

. 1989. Créoles et Enseignement du Français. Paris: . 1995. Les Créoles. Paris: Presses Universitaires de France.

Clahsen, H., J. Meisel, \& M. Pienemann. 1983. Deutsch als Zweitsprache: 
Der Spracherwerb Ausländischer Arbeiter. Tübingen: Gunter Narr. DeGraff, M. 1993. A Riddle on Negation in Haitian. Probus 5, 63-93. . 1994a. Book Review: Travaux de Recherche sur le Créole Haïtien 8. In C. Lefebvre (ed.), Journal of Pidgin and Creole Languages 9.2, 370-376.

. 1999a. Creolization, Language Change, and Language Acquisition: An Epilogue. In DeGraff (ed.), Language Creation and Language Change. Creolization, Diachrony, and Development 473-543. Cambridge: The MIT Press.

DeGraff, M. (ed.) 1999b. Language Creation and Language Change. Creolization, Diachrony, and Development. Cambridge: The MIT Press. 2001a. Morphology in Creole Genesis: Linguistics and Ideology. In M. Kenstowicz (ed.), Ken Hale: A Life in Language 53121. Cambridge: The MIT Press.

. 2001b. On the Origin of Creoles: A Cartesian Critique of Neo-Darwinian Linguistics. Linguistic Typology 5.2-3, 213-310. . (to appear). Morphology and Word-order in 'Creolization' and beyond. In G. Cinque \& R. Kayne (eds.), Handbook of Comparative Syntax. New York: Oxford University Press.

Fleischmann, U. 1984. Communication et Langages de Communication Pendant l'Esclavage aux Antilles: Contribution aux Problèmes de la Genèse des Langues Créoles. Études Créoles 6.2, 29-46.

. 1986. Das Französisch-Kreolische in der Karibik: Zur

Funktion von Sprache im Sozialen und Geographischen Raum. Tübingen: Gunter Narr.

Gilbert, G. 1983. Transfer in Second Language Acquisition. In R. Andersen (ed.), Pidginization and Creolization as Language Acquisition 168-181. Rowley, MA: Newbury House.

Holm, J. 1984. Variability of the Copula in Black English and its Creole Kin. American Speech 59.4, 291-309.

Hulk, A. 1991. Parameter Setting and Acquisition of Word-order in L2 French. Second Language Research 7.1, 1-34.

Hyams, N. 1986. Language Acquisition and the Theory of Parameters. Dordrecht: Reidel.

Jordens, P. 1988. The Acquisition of Word Order in Dutch and German as L1 and L2. Second Language Research 4.1, 41-65.

Jourdan, C. 1991. Pidgins and Creoles: The Blurring of Categories. Annual Review of Anthropology 20, 187-209.

Jourdan, C. \& R. Keesing. 1997. From Fisin to Pijin: Creolization in 
82 Noun Phrases in L2 French and Haitian: Clues on the Origin

Process in the Solomon Islands. Language in Society 26.3, 401-420. Kangni, A. 1989. La Syntaxe $d u$ Ge. Etude Syntaxique d'un Parler Gbe (Ewe): Le Ge du Sud-Togo \& Frankfurt: Peter Lang.

Kayne, R. 1984. Connectedness and Binary Branching. Dordrecht: Foris.

Koopman, H. 1986. The Genesis of Haitian: Implications of a Comparison of Some Features of the Syntax of Haitian, French and West African Languages. In P. Muysken \& N. Smith (eds.), Substrata versus Universals in Creole Genesis 231-258. Amsterdam: Benjamins.

Labov, W. 1970/1977. On the Adequacy of Natural Languages: The

Development of Tense. Linguistic Agency University of Trier, Paper 23

Series B.

Lafage, S. 1985. Français Écrit et Parlé en Pays Éwé (Sud-Togo). Paris: Société d'Études Linguistiques et Anthropologiques de France. Ph.D. Dissertation, Nice: Université de Nice.

Lalleman, J. 1983. The Principle of Elimination: Establishing Word Order Regularities in the Dutch of Foreign Workers. Linguistische Berichte 87, 40-63.

Lefebvre, C. 1986. Relexification in Creole Genesis Revisited: The Case of Haitian Creole. In P. Muysken \& N. Smith (eds.), Substrata versus Universals in Creole Genesis 279-300. Amsterdam: Benjamins. . 1998. Multifunctionality and Variation among Grammars:

The Case of the Determiner in Haitian and in Fongbe. Journal of Pidgin and Creole Languages 13.1, 93-150. . 1998b. Creole Genesis and the Acquisition of Grammar: The

Case of Haitian Creole. Cambridge: Cambridge University Press.

Lumsden, J. 1993. Relexification and Parameter Setting in Creole Genesis. In C. Lefebvre (ed.), Travaux de Recherche sur le Créole Haïtien 14, 52-69. Québec: Université du Québec à Montréal.

Lightfoot, D. 1999a. Creoles and Cues. In M. DeGraff (ed.), Language Creation and Language Change. Creolization, Diachrony, and Development 431-452. Cambridge: MIT Press.

. 1999b. The Development of Language: Acquisition, Change, and Evolution. Oxford: Blackwell.

Manessy, G. 1994. Modalités d'Appropriation d'une Langue Seconde. In D. Véronique (ed.), Créolisation et Acquisition des Langues. Aix-enProvence: Publications de l'Université de Provence.

Mather, P. 2000. Creole Genesis: Evidence from West African L2 French. In D. Gilbers, J. Nerbonne, \& J. Schaeken (eds.), Languages in Contact 247-261. Amsterdam: Rodopi. 
. 2000. Review article on Lefebvre (1998), Creole Genesis and the Acquisition of Grammar. Studies in Language 25.1, 125-137.

. (To Appear) Second Language Acquisition and Creolization:

Same (I-) Processes, Different (E-) Results. Journal of Pidgin and Creole Languages 20, 2.

Meisel, J. 1983. A Linguistic Encounter of the Third Kind or, Will the Non-real Interfere with what the Learner Does? Reply to Discussants. In R. Anderson (ed.), Pidginization and Creolization as Language Acquisition 196-209. Rowley, MA: Newbury House.

Mesthrie, R. 1992. English in Language Shift: The History, Structure and Sociolinguistics of South African Indian English. Cambridge: Cambridge University Press.

Migge, B. 1998. Substrate Influence in Creole Formation: The Origin of Give-type Serial Verb Constructions in the Surinamese Plantation Creole. Journal of Pidgin and Creole Languages 13.2, 215-266.

Mufwene, S. 2001. The Ecology of Language Evolution. Oxford: Cambridge University Press. . 2002. A Reply to Van Den Berg's Review of 'The Ecology of Language Evolution', Published on the Linguist List 13.1100 (Tuesday 23 April 2002).

Myhill, J. 1991. Typological Text Analysis: Tense and Aspect in Creoles and Second Languages. In T. Huebner \& C. Ferguson (eds.), Crosscurrents in Second Language Acquisition and Linguistic Theories 93-121. Amsterdam \& Philadelphia, PA: Benjamins.

Pienemann, M. 1984. Psychological Constraints on the Teachability of Languages. Studies in Second Language Acquisition 6.2, 186-214.

Pollock, J. 1989. Verb Movement, Universal Grammar, and the Structure of IP. Linguistic Inquiry 20.3, 365-424.

Romaine, Suzanne. 1988. Pidgin and Creole Languages. London \& New York: Longman.

Savain, R. 1993. Haitian-Kreol in Ten Steps/Dis pa Nan Kreyòl Ayisyenan. Rochester, VT: Schenkman Books.

Schwartz, B. \& R. Sprouse. 1996. L2 Cognitive States and the Full Transfer/Full Access Model. Second Language Research 12.1, 40-72.

Singler, J. 1996. Theories of Creole Genesis, Sociohistorical Considerations, and the Evaluation of Evidence: The Case of Haitian Creole and the Relexification Hypothesis. Journal of Pidgin and Creole Languages $11.2,185-230$.

Tomaselli, A. \& B. Schwartz. 1990. Analysing the Acquisition Stages of 
84 Noun Phrases in L2 French and Haitian: Clues on the Origin

Negation in L2 German: Support for UG in Adult SLA. Second Language Research 6.1, 1-38.

Tremblay, M. 1991. Possession and Datives: Binary Branching from Lexicon to Syntax. Ph.D. Dissertation, Montreal: McGill University.

Vainikka, A. \& M. Young-Scholten. 1996. Gradual Development of L2 Phrase Structure. Second Language Research 12.1, 7-39.

Valdman, A. 1978. Le Créole: Structure, Statut et Origine. Paris: Klincksieck.

1983. Basic Course in Haitian Creole. The Hague: Mouton.

Véronique, D. 1984. The Acquisition and Use of Aspects of French Morphosyntax by Native Speakers of Arabic Dialects. In R. Andersen (ed.), Second Languages: A Crosslinguistic Perspective 191-213. Rowley, MA: Newbury House.

White, L. 1986. Implications of Parametric Variation for Adult Second Language Acquisition: An Investigation of the Pro-drop Parameter. In V. Cook (ed.), Experimental Approaches to Second Language Acquisition. Oxford: Pergamon Press.

White, L. 1987. Markedness and Second Language Acquisition: The Question of Transfer. Studies in Second Language Acquisition 9, 261286.

Zobl, H. 1980. Developmental and Transfer Errors: Their Common Bases and (Possibly) Differential Effects on Subsequent Learning. TESOL Quarterly 14.4, 469-482. 